\title{
Infusing Technology into Customer Relation- ships: Balancing High-Tech and High-Touch
}

\author{
Harald Salomann, Lutz Kolbe and Walter Brenner \\ Institute of Information Management, University of St. Gallen, Switzer- \\ land. (Harald.Salomann, Lutz.Kolbe, Walter.Brenner)@unisg.ch
}

\section{Introduction}

In today's business environment, self-service is becoming increasingly important. In order to promote their self-service activities, banks have created online-only products and airlines offer exclusive discounts for passengers booking online. Self-service technologies' practical applications demonstrate this approach's potential. For example, Amtrak introduced an IVR (Interactive Voice Response) system, allowing cost savings of $\$ 13 \mathrm{~m}$; likewise Royal Mail installed an IVR system leading to a reduction of its customer service costs by $25 \%$ (Economist 2004).

On the other hand, the substitution of human contact with self-service technology is not always as successful as expected. For example, a study conducted by the market research company Forrester, in which 110 large companies were surveyed, shows that IVR systems meet customers' needs only $18 \%$ of the time, which is less than any other type of customer contact (Temkin et al. 2004).

These contradicting facts motivated the authors to examine self-services in customer relationships from companies' perspective. The research questions derived from the above outlined observations are as follows: Firstly, what is the actual status quo of the self-service domain? Secondly, how can self-services be successfully designed and implemented in practice if based on the findings regarding the status quo?

In order to address these research questions, a survey was conducted of renowned companies' CRM (Customer Relationship Management) executives in the German-speaking countries. Prior to this survey, the authors had conducted an extensive literature review. This also served as the basis of the survey's questionnaire.

The paper starts by presenting the theoretical concepts of self-services and self-service technology (SST) in the context of customer relationships. After this the research methodology and the survey design are outlined. The 
following section discusses self-services' status quo in customer relationships. The research findings culminate in a framework for the successful design and implementation of self-services. Finally, the paper concludes with a few remarks highlighting the limitations of as well as the contributions to further research stemming from this effort.

\section{Theoretical Background}

\section{From Transactions to Relationships}

Ever increasing competition and a simultaneous decrease in customer loyalty have led to the emergence of concepts that focus on the establishment and nurturing of relationships with customers. Customer relationship management emerged as a combination of different management and information systems approaches, in particular relationship marketing and technology-oriented approaches such as computer-aided selling and sales force automation.

Relationship marketing was the first systematic approach to the development of buyer-seller relationships. It can be defined as an integrated effort to identify, build up and maintain a network with individual customers and to continuously strengthen the network through interactive, individualized and value-added contacts for both sides' mutual benefit over a long period of time (Shani/Chalasani 1992).

The concept of CRM and its different perspectives and implications (i.e. process, strategy, philosophy, capability and technology) have been widely discussed by marketing practitioners and scholars alike. For our research purposes, we follow a process-oriented approach by Shaw and Reed (Shaw/Reed 1999), who define CRM as an interactive process achieving the optimum balance between corporate investments and the satisfaction of customer needs to generate the maximum profit.

\section{Self-Service Concept}

\section{Characteristics of Self-Service}

In a self-service system, the degree of a consumer's direct and active involvement in the service process is higher than that in other service systems. For example, Wikström refers to self-service as "a sort of joint venture in the marketplace, in which the consumer increasingly assumes the 
role of co-producer." (Wikström 1996) Consequently, the component 'self' in the term 'self-service' points to two important aspects:

In the context of a service's process dimension, the consumer's increased involvement in and integration into a service's workflow characterize self-service in comparison to "traditional' service systems. The customer is involved "in tasks once done for her or him by others." (Toffler 1970)

In the context of self-service interactions between the consumer and service provider, the human element is eliminated from the service provider's side. Consequently, the interaction type 'human-human' is not part of the self-service concept. The 'high-touch' that usually characterizes services is replaced with 'high-tech'. In the current literature, technology is considered an enabler of self-service offerings. It is becoming ever more important. This development is demonstrated by the increased use of terms such as 'technology-based self-service' (Dabholkar 1996) and 'self-service technology' (Meuter et al. 2000).

\section{Self-Services in Customer Relationships}

The current literature in the self-service domain emphasizes the realization of potential cost savings as a prominent motive for companies to introduce self-services into customer relationships (e.g., Meuter et al. 2000). Since self-services enable non-human service interactions, personal care is substituted with technological solutions, which makes tremendous labor cost savings possible.

Furthermore, an ever-growing number of customers demand, and even expect, a self-service alternative. The targeting of this customer segment is therefore a main driver of the increasing importance of self-services in customer relationships. For example, one key element of Wells Fargo's strategy is to provide its customers with alternative delivery channels (Bitner et al. 2002). Consequently, Wells Fargo was the first bank in the U.S. to offer online banking to its customers. Wells Fargo's findings show that their online customers are the most satisfied and most loyal customer group.

Studies examining self-services in customer relationships also show that self-services are particularly appealing to a tech-savvy customer segment asking for more control over the service process and higher flexibility in terms of time (e.g., Bateson 1985). This aspect is also reflected in current self-service strategies in practice. For example, Blue Shield of California, a U.S.-based insurance company, offered online self-services after conducting research with focus groups composed of customers as well as potential health customers ('mylifepath.com') (Gallagher 2002). 


\section{Research Methodology}

The authors of this paper conducted a survey aimed at examining the current status quo and future challenges in the CRM area with particular regard to critical success factors and common pitfalls. In addition to a more general CRM part, the survey also included a part that was specifically dedicated to self-services in customer relationships. The overall goal of this particular part of the survey was to identify and document the actual status quo in this area. In order to address these objectives, a questionnaire, aimed at eliciting a detailed description of the current activities in the selfservice domain, was developed specifically for this focus topic's requirements.

The survey was carried out in the second half of 2004. 1,000 decision makers in the German-speaking regions (i.e. Germany, Austria and Switzerland), who are in charge of their companies' CRM activities, were invited to participate. An individually addressed email invitation explained the purpose of the research and included a link to the survey's online platform. Finally, this yielded a total of 89 responses for the general CRM study, equaling a return rate of approximately $9 \%$. Of the 89 respondents, 44 actually utilize self-services. The details described in the following only refer to the self-service part of the survey.

The survey participants, who offer self-services to their customers, belong to a variety of different industries. The industry represented most often is "Banking/Financial Services" at 39\%, followed by "Insurance" (20\%) and "Telecommunications" (11\%). Although this can be partially traced to the composition of the CRM survey's overall sample, it also allows the conclusion to be drawn that these industries, which represent approximately $59 \%$ of the self-service sample size, are currently placing most emphasis on self-services and the application of SST in customer relationships.

The majority of the participating companies (i.e. 26 of 44) are located in Germany. Fourteen companies are based in Switzerland and four firms are from Austria. The respondents are mainly representatives of large-scale enterprises in terms of number of employees as well as turnover per year. 


\section{Status Quo of Self-Services in Customer Relationships}

\section{Direction of Current Self-Service Activities}

Currently, many companies (about 55\%) refer to self-services as a matter of separate, divisional or channel-specific initiatives. Similarly, $20 \%$ of the companies described their self-service activities as single projects with no interaction with other projects. Only approximately $25 \%$ of the firms initiate coordinated, enterprise-wide self-service projects.

Companies mentioned cost reduction most often when asked about their motivation for the introduction of self-services in customer relationships. This goal adds up to a total percentage of around $86 \%$, which highlights companies' widespread belief that self-service is an efficiency tool facilitating processes' streamlining through the elimination of media conversions and the reduction of idle time. Approximately $77 \%$ of the companies in our survey maintained that increasing customer satisfaction and loyalty are also motivations for the utilization of self-services. Compared to these figures, only about $32 \%$ of the companies declared deploying SST in order to reach new customer segments.

Furthermore, about $86 \%$ of the polled companies maintained that they offer retail customers self-services, whereas approximately $73 \%$ provide business customers with a self-service option. Many companies also consider service management employees as an attractive target group for selfservice offerings. The majority of the respondents (around 64\%) offer selfservices to this group of employees in order to support the interaction with the customer.

The survey results show that self-services are most often used in the areas of transactions and customer service. Approximately $70 \%$ of the polled firms stated that they deploy self-service offerings in order to support transactions directed towards the interaction with an individual customer. Around $66 \%$ of the companies utilize SST for customer service concerning interactions that are one way or another related to supporting a company's core product.

\section{Usage of Technology}

As already pointed out before, the application of technology is a typical characteristic of self-service systems. The survey's results indicate that Internet technology plays a key role in the self-services context. Almost all companies (around 96\%) maintained that they utilize the Internet as an interface for offering their customers self-services. According to our survey, 
popular applications of this SST are FAQs (Frequently Asked Questions) on websites and online tracking and tracing services.

The telephone/voice interface is ranked second in respect of the remaining SSTs. Exactly $50 \%$ of the firms participating in the survey use telephone self-services. The examples most frequently mentioned by the participants were fax-on-demand, IVR and voice recognition technologies.

Only approximately $32 \%$ of the companies utilize interactive kiosks as an SST. This result emphasizes the fact that the usage of kiosks in service management is decreasing due to Internet technology's popularity and diffusion in recent years.

Lastly, around $16 \%$ of the polled companies use video/CD technology in the context of self-service offerings. Video and TV-based training for customers is a common application of this self-service interface.

\section{Benefits and Shortcomings}

The majority of companies (around 84\%) refer to the realization of cost reductions as the biggest benefit of self-services. The reduction of process cycle time is almost as important as cost savings. This benefit was named by 36 of 44 companies (equaling approximately 82\%). Furthermore, the elimination of media conversion is regarded as yet another benefit by approximately $43 \%$ of the companies. These results underpin the prevalent argument that efficiency gains in terms of time and money are the main advantages of SST.

However, besides these benefits listed above, $25 \%$ of the companies referred to other advantages. These comprise aspects such as an increased freedom of choice for customers, generation of leads, identification of prospects, and the positioning of the company as an innovation leader. These benefits demonstrate that self-service is not only about 'reducing' time and costs. It is also about 'enhancing' a company's strategic options and capabilities.

As far as the shortcomings of SST are concerned, 30 of 44 companies (equaling about $68 \%$ ) characterize customers' lack of acceptance of SST as the main shortcoming. The causes of this lack of acceptance as based on the firms' experiences were also cited. One reason is the shifting of tasks formerly performed by the company to customers. Many customers are not willing to accept this shift of tasks. Consequently, they refuse to make use of SST. Another frequently mentioned reason is that self-services usually only appeal to a certain, tech-savvy customer segment.

Another disadvantage closely related to insufficient acceptance is the lack of personal contact with customers which results in weak social 
bonds. This shortcoming was mentioned by 24 companies, equaling approximately $55 \%$. A further consequence of this lack of personal contact is the severely limited advisory service. Since this advisory service is missing in self-service interactions, it is also almost impossible to identify the same degree of cross- and up-selling potential as would be possible in a face-toface meeting.

\section{Discussion of the Status Quo}

The empirical findings (see also Fig 1) reveal that about half of the polled companies actually offer their customers self-services (i.e. 44 out of 89 companies). Therefore, although self-service is on many companies' agenda, there is still a considerable potential for growth, which leads to the conclusion that self-service is here to stay. Currently, however, selfservices are primarily offered by financial services, banking and insurance companies.

\begin{tabular}{|c|c|c|c|c|c|}
\hline \multicolumn{6}{|c|}{ Self-Services in Customer Relationships } \\
\hline $\begin{array}{l}\text { Organizational } \\
\text { alignment }\end{array}$ & $\begin{array}{l}\text { Divisional, channel- } \\
\text { specific }\end{array}$ & \multicolumn{2}{|c|}{$\begin{array}{l}\text { Enterprise-wide } \\
\text { program of projects }\end{array}$} & \multicolumn{2}{|c|}{ Single project } \\
\hline $\begin{array}{l}\text { Ranking } \\
\text { (Percentage) }\end{array}$ & $\begin{array}{c}1 \\
(55 \%)\end{array}$ & \multicolumn{2}{|c|}{$\begin{array}{c}2 \\
(25 \%)\end{array}$} & \multicolumn{2}{|r|}{$\begin{array}{c}3 \\
(20 \%)\end{array}$} \\
\hline $\begin{array}{l}\text { Motivation for } \\
\text { introduction }\end{array}$ & Cost reduction & \multicolumn{2}{|c|}{$\begin{array}{l}\text { Increase customer } \\
\text { satisfaction and loyalty }\end{array}$} & \multicolumn{2}{|c|}{$\begin{array}{l}\text { Reach new customer } \\
\text { segments }\end{array}$} \\
\hline $\begin{array}{l}\text { Ranking } \\
\text { (Percentage) }\end{array}$ & $\begin{array}{c}1 \\
(86 \%)\end{array}$ & \multicolumn{2}{|c|}{$\begin{array}{c}2 \\
(77 \%)\end{array}$} & \multicolumn{2}{|r|}{$\begin{array}{c}3 \\
(32 \%)\end{array}$} \\
\hline Scope & Transactions & \multicolumn{2}{|c|}{ Customer service } & \multicolumn{2}{|c|}{ Education } \\
\hline $\begin{array}{l}\text { Ranking } \\
\text { (Percentage) }\end{array}$ & $\begin{array}{c}1 \\
(71 \%)\end{array}$ & \multicolumn{2}{|c|}{$\begin{array}{c}2 \\
(66 \%)\end{array}$} & \multicolumn{2}{|r|}{$\begin{array}{c}3 \\
(39 \%) \\
\end{array}$} \\
\hline $\begin{array}{l}\text { Deployed } \\
\text { technology }\end{array}$ & Internet & Telephone & Interactiv & e Kiosks & Video/CD \\
\hline $\begin{array}{l}\text { Ranking } \\
\text { (Percentage) }\end{array}$ & $\begin{array}{c}1 \\
(96 \%)\end{array}$ & $\begin{array}{c}2 \\
(50 \%)\end{array}$ & & $\begin{array}{l}3 \\
3 \%)\end{array}$ & $\begin{array}{c}4 \\
(16 \%)\end{array}$ \\
\hline
\end{tabular}

Fig. 1. Status Quo of Self-Services in Customer Relationships

Furthermore, companies are beginning to realize that the self-service approach is not just about cutting costs and improving efficiency. Although this is still the motive that was most frequently mentioned by the participating firms, increasing customer satisfaction and loyalty is almost equally important. A few participants explicitly referred to self-services as a way of enhancing a company's strategic options.

The results of our survey point towards one key challenge: SST constitutes a 'double-edged sword' for companies that are unable to find the 
right balance between high-tech and high-touch. This is caused by the fact that self-services' strengths are simultaneously their main weaknesses. On the one hand, utilization of SST makes tremendous cost savings possible. The downside of service automation is, however, a lack of customer acceptance, weak social bonds and a loss of personal contact and client control.

\section{A Framework for Self-Services in Customer Relationships}

Within the scope of our study we also asked the participants what they considered important for self-services' design and implementation, be it good ('best practice') or bad ('lessons learned'). For this reason, we included a section in the questionnaire were participants had the opportunity to comment on their first-hand experience with self-service technology. Based on these comments, we identify four critical factors that should be considered for self-services in customer relationships.

\section{Development of a Focused Self-Service Strategy}

Most companies commenting on unsuccessful self-service initiatives put the blame on a diffuse strategic impetus resulting in a lack of focused selfservice activities. Our survey findings reveal that successful firms focus their self-service activities in terms of their goals and scope. They gear their self-service strategy towards one primary goal aligned with their particular business strategy. The primary goal of a focused self-service strategy is typically one of the following: cost reduction, increased customer satisfaction and loyalty, or development of new customer segments.

Furthermore, companies focus their self-service offerings within a certain scope instead of covering the whole range. According to our survey results, two main directions can be differentiated: transaction orientation and knowledge seeking.

The first direction aims at supporting customers' transactions by means of SST. This transaction-driven self-service is directed towards an individual's relationship with the company and follows a specific objective. It is only, however, relevant at a particular moment in time. This type of selfservice requires standardized processes with real-time information and contextual knowledge delivery. Examples are completing an order online, changing an address and the tracking and tracing of an order's status.

The second direction is geared towards knowledge-seeking interactions aimed at providing and exchanging knowledge between a company and its customers. This knowledge-driven self-service concerns generalized in- 
formation about the company's products and procedures such as inquiries concerning product usage, troubleshooting, warranty information and store locations. This type of self-service interaction requires extensive search and retrieval functionalities as well as logic to identify the appropriate knowledge required for the customer's inquiry.

\section{Change and Awareness within the Organization}

Self-services are affecting and changing companies on an organizational level. Very often companies underestimate this fact and consider selfservices as a solely technological challenge, or something that can be left to a single department within the organization. Our survey findings emphasize the fact that the majority of companies perform self-service activities as a matter of separate, divisional or channel-specific initiatives.

Only a small number of companies are fully aware of the enterprisewide implications of self-service activities. However, these are the ones that are achieving success in the self-service domain. Our research shows that successful firms sensitize the whole organization by spanning their self-services activities across departmental boundaries instead of limiting them to organizational 'silos'. In this context, the launch of enterprisewide projects and the integration of efforts across all customer touch points pave the way for the successful design and implementation of selfservices.

\section{Internet Technology as a Self-Service Enabler}

Technology is a key enabler of the creation of a compelling self-service experience for customers. Following our survey findings, we conclude that successful companies fully grasp technological advances' limits and benefits with regard to their suitability for self-service environments. The technology most appropriate for the successful design of self-services is the Internet (although the Internet is more than a self-service technology). The diffusion of the Internet and its 'anytime, anywhere' characteristics ensure a company's accessibility by turning it into a 'virtual store' that is permanently accessible from (almost) anywhere.

Internet technology also allows firms to identify customers' needs and to tailor self-services to meet a customer's needs throughout his/her individual customer process phases. The Internet's technological enhancements furthermore enable service providers to personalize their selfservices. According to the survey participants, personalized self-services have a positive impact on customer relationships because customers feel 
that they are truly known and individually acknowledged by a firm along the customer process. The survey participants' comments indicated that this personalization of self-services is more important than the offering of price discounts as incentives. The survey results show, moreover, that companies are also not willing to allow price discounts, as this would diminish the potential cost savings they are hoping for.

Our research findings indicate that other SSTs are less likely to match the specific needs of self-service systems due to their restrictions in terms of time and location. Kiosks can, for example, only be accessed at certain locations, whereas the Internet is not as limited in this regard.

\section{Integration of Self-Service Activities}

Another critical success factor that has to be considered in self-service design is the integration of the self-service world into traditional channels. According to our research results, companies excelling at this discipline do so by leveraging their self-service activities by means of running a common platform for self-services as well as all other customer interactions. Integrated systems are a prerequisite for such a strategy.

In this context, successful companies consider the self-service channel as complementary to, rather than a substitute for, other channels. For example, if a user opts out of a self-service channel, companies that successfully integrated self-service channels with their 'traditional' channels are able to pass the self-service channel's information to the call center agent in real-time. Consequently, the customer always has the choice to resort to a 'traditional' channel without going through repetitive authentication procedures and answering redundant questions concerning his/her inquiry.

The integration of self-service activities also includes making the selfservice platform available to both customers and to contact center employees as a tool for helping customers. This assists companies in ensuring consistency of information across all interfaces and channels. Such an approach avoids the sending of 'mixed messages' to customers.

\section{A Framework for Self-Service Design}

Based on our findings outlined in the sections above, we propose a framework as is illustrated in Fig 2. This proposed self-service framework is based on an earlier framework describing the necessary elements for successful CRM initiatives. The initial CRM framework was the result of ongoing research that combines theoretical conceptualization efforts with practical application. The theoretical findings of this research, which have 
been introduced to the research community, elaborate on eight years of case study and action research in conjunction with quantitative research methods (e.g., Gebert et al. 2003; Bueren et al. 2005). The research results have also been discussed and validated in practice through collaboration with research partners.

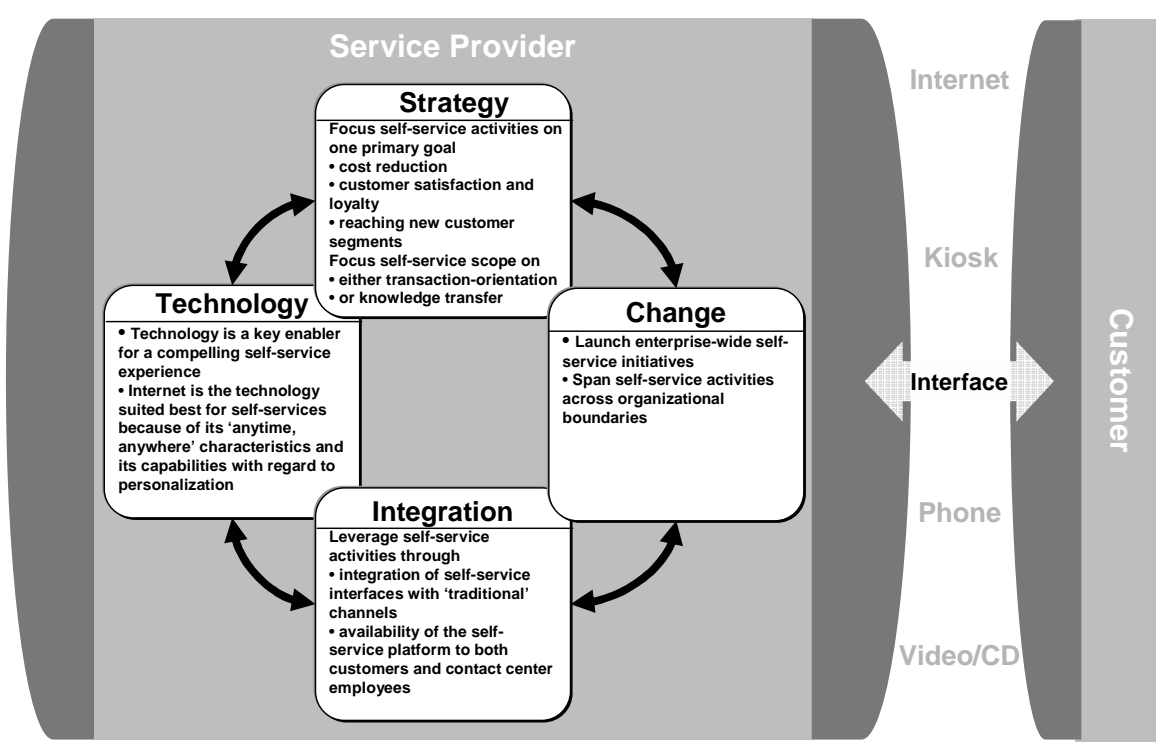

Fig. 2. Framework for Self-Service Design

\section{Limitations and Directions for Future Research}

The authors did not intend to investigate self-services in customer relationships in any hypothetic-deductive way at this point. Nevertheless, the survey's results should support the development of future theory and models in this field with particular reference to the successful use of technology in self-service systems. The proposed framework will be further refined and substantiated by means of in-depth industry case studies.

The sample size for the empirical study is relatively small, although within the range found in many other studies in this area (e.g., Xue et al. 2005). The study is also limited to the German-speaking area and lacks generalizability within a specific industry. Future research can shed light on the analysis of self-services outside the German-speaking area and may focus on a specific industry. The internationalization of research in this 
field may also give rise to cultural issues as an emerging theme in the area of self-services in customer relationships.

\section{References}

Bateson, JEG (1985) Self-Service Consumer: An Exploratory Study. Journal of Retailing, vol 61, no 3, pp 49-76

Bitner MJ, Ostrom, AL, Meuter ML (2002) Implementing successful self-service technologies. In: Academy of Management Executive, vol 16, no 4, pp 96-109

Bueren A, Schierholz R, Kolbe L, Brenner W (Forthcoming) Improving Performance of Customer Processes with Knowledge Management. In: Business Process Management Journal

Dabholkar PA (1996) Consumer Evaluations of New Technology-Based SelfService Options: An Investigation of Alternative Models of Service Quality. In: International Journal of Research in Marketing, vol 13, pp 29-51

Economist (2004) You're hired, September 16th

Gallagher J (2002) Balancing between High-Tech \& High-Touch. In: Insurance \& Technology, vol 27, no 3, pp 22-27

Gebert H, Geib M, Kolbe LM, Brenner W (2003) Knowledge-Enabled Customer Relationship Management. Journal of Knowledge Management, vol 7, no 5, pp 107-123

Meuter ML, Ostrom A, Roundtree RI, Bitner MJ (2000) Self-Service Technologies: Understanding Customer Satisfaction with Technology-Based Service Encounters. Journal of Marketing, vol 64, no. 3, pp 50-64

Shani D, Chalasani S (1992) Exploiting Niches Using Relationship Marketing. The Journal of Consumer Marketing, vol 9, no 3, pp 33-42

Shaw R, Reed D (1999) Measuring and Valuing Customer Relationships: How to Develop the Measures that Drive Profitable CRM Strategies. Business Intelligence, London

Temkin BD, Manning H, Sonderegger P, Amato M (2004) Scenario Design: A Disciplined Approach to Customer Experience. Forrester

Toffler A (1970) Future Shock. Amereon Ltd., New York

Wikström S (1996) Value Creation by Company-Consumer Interaction. Journal of Marketing Management, vol 12, no 5, pp 359-374

Xue M, Hein GR, Harker PT (2005) Consumer and Co-Producer Roles in eService: Analysing Efficiency and Effectiveness of e-Service Designs. International Journal of Electronic Business, vol 3, no 2, pp 174-197 